\title{
Active ゾーンを形成した図書館におけるファミリー利用の特徴 地域公共図書館における開架フロアのゾーニング手法に関する研究 (4) \\ THE CHARACTERISTICS OF FAMILY USE AT A PUBLIC LIBRARY WITH AN ACTIVE ZONE
}

Studies of the method of zoning an open shelf floor at public libraries (4)

\author{
北 岡 敏 郎*
}

Toshiro KITAOKA

\begin{abstract}
The purpose of this study is to show that the method of zoning an open shelf floor with a popular library area is more reasonable and effective at public libraries. According to this method an open shelf floor is divided into two zones at public libraries. One is an "active zone" which consists of a popular library area with a children's book area, a newspaper and magazines' area and an AV materials' area. The other is a "quiet zone"which consists of other adults' book area with a reference area.

This research paper on the method of zoning an open shelf floor at public libraries shows that most children,especially infants and lower grade pupils, can leave their parents to use the children's book area, and after getting books of their preference, they read them beside their parents, and again they leave their parents to get another book. As a result,many children and their parents stay mainly at the children's book area, and many children and their parents can stay at the popular library area or the newspaper and magazines' area, too ,if each area is ful of seats.Most parents who use books,on the other hand,use popular library books in the active zone, and approximately half of them use adults' books in the quiet zone in a short time.Most parents who use books tend to use not only books but also magazines.
\end{abstract}

Keywords: public library, open shelf floor, zoning, popular library area, family use

地域公共図書館, 開架フロア,ゾーニング, ポピュラーライブラリーエリア,ファミリー利用

1.はじめに

地域公共図書館が開架式になって以来、開架フロアのエリア配置 構成はあまり検討されておらず、近年の施設や資料の種類・数が充 実する中で、特に利用面から実証されたエリアの再配置計画が求め られる。

著者は、地域公共図書館の利用を調査し、近年の利用の特徵とし て成人の複合利用と幼児・児童のファミリ一利用を捉え、前者では 一般書エリアと新聞・雑誌エリアを隣接させた配置構成が、後者で は児童書エリアと一般書エリアを隣接させた配置構成がそれぞれの

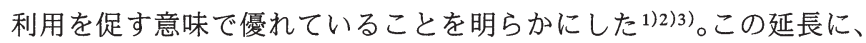
これら二つの利用に対応したエリア配置構成として、Active ゾーン とQuietゾーンによるゾーニング構成を考えている。すなわち、本研 究は、地域公共図書館の開架フロアにおいて、一般書エリアをポ ピュラーライブラリーエリア注1) とそれ以外とにわけ、前者は新聞・ 雑誌エリアや児童書エリアなどと隣接させてエリア間の活発な利用 を促すActiveゾーンを形成し、後者はレファレンスエリアなどと Quietゾーンを形成するゾーニング手法を提案し、この手法の妥当性 と有効性を明らかにする一連の研究である。

前二編 ${ }^{4) 5}$ において、既存図書館の配架の工夫から、ポピュラーラ イブラリーを構成する主要書籍として NDC 分類の $<59$. 家政学・生 活科学>が考えられること、これをポピュラーライブラリーの核と して位置付け、全国の図書館でどのようにポピュラーライブラリー
エリアが形成され、どこに配置されているかを分析し、提案する ゾーニング手法の妥当性と意義を明らかにした。また、前編6)では、 ActiveゾーンとQuietゾーンを形成した図書館利用の特徵を成人の複 合利用から明らかにした。本編は、もう一つの対象である子どもが 親と同伴して来館するファミリー利用について、図書館利用の特徵 を明らかにする。

課題と方法: ファミリー利用を対象に、Activeゾーンと Quietゾー ンの利用の特徵、及び、ポピュラーライブラリーエリアの創出が書 籍利用と複合利用にどのような影響を与えるかを明らかにすること が課題である。分析の方法は以下のとおりである。

(1) ファミリー利用については、既編2)3）同様、子どもと親の主 目的利用の有無及び付き添いの仕方から、ファミリ一利用の型を設 定し、どのような利用型構成になるかを明らかにする。具体的には、 付き添い利用は、子どもに主目的利用があるく子主体-親付き添い> 型、親に主目的利用があるく親主体-子つきまとい>型、両者に主目 的利用があるく交互付き添い>型の三つである。分離利用は、両者 に主目的利用があり、かつ、両者が離れて主目的利用を行うもので、 滞在時間のどこで分離するかから、はじめに短く分離し長く付き添 うく前半分離 $>$ 型、ほとんどを付き添い後半に短く分離するく後半 分離 $>$ 型、滞在時間のほとんどを分離する<完全分離 $>$ 型、分離と 付き添いを繰り返すく繰り返し＞型の四つである。

（2）複合利用については、前編 ${ }^{6}$ ) 同様、三つの資料（書籍、新聞・

\footnotetext{
* 有明工業高等専門学校建築学科 教授·博士 (人間環境学) Prof., Dept. of Architecture, Ariake National College of Technology, Ph. D.
} 
雑誌、 $\mathrm{AV}$ 資料)の利用の仕方から資料の種別利用型を設定し、ポピュ ラーライブラリーエリアを設けた場合、どのような利用型構成にな るかを明らかにする。

具体的には、それぞれの単種利用としてAV資料だけのA型 (audiovisual)、書籍だけの B 型（book）、新聞・雑誌だけの M 型（magazine） であり、複合利用はそれらの組合せから $\mathrm{AB}$ 型、BM型、AM型、 $\mathrm{ABM}$ 型が設定でき、これらに、配架資料の利用がない返却等手続きのみ を $\mathrm{O}$ 型として加え、8 類型である。これまで成人については分析し ているが、今回、子どもの種別利用型構成も明らかにする。

（3）書籍を利用する親は、ポピュラーライブラリーエリアの書籍 (以下、ポピュラーブック) と一般書エリアの書籍（以下、一般書） をどのように利用するかを明らかにする。その際、ポピュラーライ ブラリーの構成方式が問題となる。前編 ${ }^{6}$ ) の成人の単独利用 (以下、 成人の単独利用）においては、多くの類目からそれぞれの一部を抜 き出したく多類目抽出〉方式と取り出す綱目数を限定してそのほと んどを取り出すく特定綱目一括〉方式では、一般書とポピュラー ブックの利用の仕方が異なる傾向がみられた。ファミリ一利用の親 においてどのような構成方式の影響があるかを明らかにする。

調査対象図書館：調査対象は、前編 $\left.{ }^{6}\right)$ と同様、 $\mathrm{S}$ 町立図書館（以 下、 $\mathrm{S}$ 館）と H市立図書館（以下、H 館）である。概要を示すと、前 者は、ActiveゾーンとQuietゾーンが中庭を挟んで形成されているた
め（図 1)、ゾーン間の見通しはよい。Active ゾーンには児童書、雑 誌、ポピュラーライブラリー、AVの各エリアがカウンターの向かい 側にまとまって配置され、エリア間には壁がなく自由に行き来でき る。ただ、AVエリアはホールを挟んで向かい側に視聴コーナーがあ る注2)。奥のQuietゾーンには、一般書と郷土資料・レファレンス、及 び新聞エリアと文庫本のエリアがある。後者の $\mathrm{H}$ 館は、Active ゾー ンと Quiet ゾーンが入り口と事務室を挟み反対側に位置するため注3) (図2)、ゾーン間は見通しにくい。建物規模が小さい上にActiveゾー ンは各エリアが詰まっているため、エリア間も見通しにくく、ポ ピュラーライブラリーエリアの机は雑誌読書と兼用させたものと なっている注4)。

これら二つの図書館は、建物や蔵書規模がかなり異なり、雑誌夕 イトル数、 $\mathrm{AV}$ 資料数注 5 )、座席数に差がある他（表 1 )、特にポピュ ラーライブラリーの構成方式が異なり、 $\mathrm{S}$ 館は $<59$. 家政学・生活科 学 >以外に九つの類目の一部を持ち込んだく多類目抽出 $>$ 方式であ り (表 2)、 $\mathrm{H}$ 館は 59 以外に綱目 00 総記、 29 歴史、 52 建築学と 7 類 芸術のほとんどを持ち込んだく特定綱目一括＞方式である。

調査概要 : この 2 館を対象に、 $S$ 館は平成 14 年 6 月、 11 月、 12 月 の休日 5 日間に、 $\mathrm{H}$ 館は平成 16 年 7 月、11月の休日 4 日間について、 開館から閉館まで幼児や児童が親同伴で来館したファミリーを追跡 調查し、平面図に入館から退館までの動線、場所と行為及び着座の

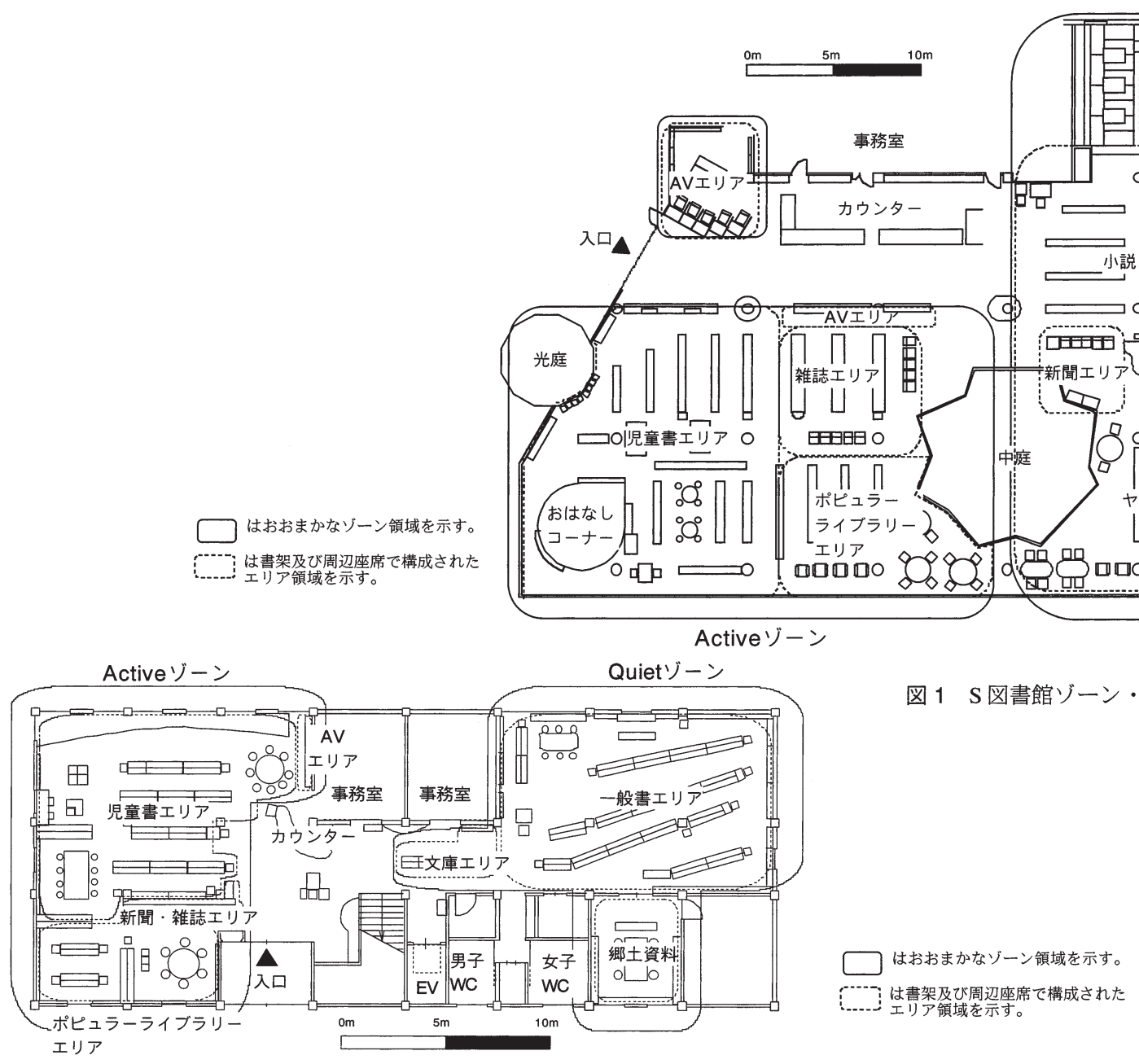

図 2 H図書館ゾーン・エリア構成 
表 1 図書館概要・調査概要

\begin{tabular}{|c|c|c|c|}
\hline \multicolumn{2}{|l|}{ 図畫館 } & S図書館 & H図書館 \\
\hline \multicolumn{2}{|l|}{ 延床面積 } & $2032.74 \mathrm{~m}^{2}$ & $908.52 \mathrm{~m}^{2}$ \\
\hline \multirow[t]{6}{*}{ 凟料数 } & 蔵書数 & 100,658 冊 & 93,471 冊 \\
\hline & （一般書） & 82,392 冊 & 61,573 冊 \\
\hline & （児童書） & 18,266 冊 & 31,898 冊 \\
\hline & 雑誌夕イトル数 & 300タイトル & 97タイトル \\
\hline & 新聞種数 & 12紙 & 18紙 \\
\hline & $A V$ 点数 & 3,441 点 & 1,524 点 \\
\hline \multicolumn{2}{|l|}{ 貸出制限 } & 制限なし・15日間 & 1人5冊·15日間 \\
\hline 調査時 & Active ソーン & 56 (席) & 42 (席) \\
\hline \multirow[t]{6}{*}{ 座席数 } & 児童書エリア & 28 & 28 \\
\hline & $\begin{array}{c}\text { ボヒュラーライフラ } \\
\text { リーエリア }\end{array}$ & 16 & 14 \\
\hline & $\mathrm{AV}$ エリア & 5 & 0 \\
\hline & 新聞・雑誌エリア & 7 & 0 \\
\hline & Quiet ソーン & 73 & 29 \\
\hline & 計 & 129 & 71 \\
\hline \multirow[t]{4}{*}{ 調査概要 } & 調査年 & 平成14年 & 平成16年 \\
\hline & 月日 & $\begin{array}{l}6 / 16,23,30 \\
11 / 10,12 / 1\end{array}$ & $\begin{array}{c}7 / 17 、 18 、 25 、 \\
11 / 21 \\
\end{array}$ \\
\hline & 対象家族数 & 61組 & 55組 \\
\hline & サンプル数 & 子ども88、親69人 & 子ども90、親62人 \\
\hline \multicolumn{2}{|l|}{ 資料年度 } & 平成14年3月末 & 平成16年3月末 \\
\hline
\end{tabular}

表 3 サンプルの家族構成

\begin{tabular}{|c|c|c|c|c|c|c|c|c|c|}
\hline \multirow{3}{*}{ 図書館 } & \multirow{3}{*}{ 子どもの人数 } & \multicolumn{4}{|c|}{ 親1人 } & \multirow{2}{*}{\multicolumn{2}{|c|}{ 親2人 }} & \multirow{2}{*}{\multicolumn{2}{|c|}{ 合計 }} \\
\hline & & \multicolumn{2}{|c|}{ 母親 } & \multicolumn{2}{|c|}{ 父親 } & & & & \\
\hline & & 組 & (\%) & 組 & (\%) & 組 & (\%) & 組 & (\%) \\
\hline \multirow{4}{*}{ S図書館 } & 1人 & 26 & 42.6 & 4 & 6.6 & 6 & 9.8 & 36 & 59.0 \\
\hline & $2 \lambda$ & 18 & 29.5 & 3 & 4.9 & 2 & 3.3 & 23 & 37.7 \\
\hline & 3人以上 & 2 & 3.3 & - & & - & & 2 & 3.3 \\
\hline & 合計 & 46 & 75.4 & 7 & 11.5 & 8 & 13.1 & 61 & 100.0 \\
\hline \multirow{4}{*}{ H図畫館 } & $1 \lambda$ & 16 & 29.1 & 5 & 9.1 & 2 & 3.6 & 23 & 41.8 \\
\hline & $2 \lambda$ & 20 & 36.4 & 5 & 9.1 & 5 & 9.1 & 30 & 54.5 \\
\hline & 3人以上 & 1 & 1.8 & 1 & 1.8 & - & & 2 & 3.6 \\
\hline & 合計 & 37 & 67.3 & 11 & 20.0 & 7 & 12.7 & 55 & 100.0 \\
\hline
\end{tabular}

有無、利用時間等を記録し、1分以上継続した行為を集計した。なお、 作為的にならないよう一組の調査が終わると入口の外で待機し、次 に来館したファミリーを調查対象とした注6)。また、退館時に子ども の学年と家族構成等をヒヤリングした。休日としたのはファミリー 利用が多いためであり、調査日数が異なるのは、統計にたえるよう 各館の対象家族数 60 組、子ども 100 人を目標としたためである。調 查時期から数年経っているが、前編 ${ }^{6)}$ の成人の単独利用と比較する ためには、同時期に調査したものが有効である。

得られたサンプル数は表 1 のとおりであり、サンプルの家族構成 は親 1 人が両館とも約 $87 \%$ 占め (表 3)、親の性別は母親が $70 \sim 78$ $\%$ と圧倒的に多い注7)。子どもは、1人が S 館約 $59 \%$ に対し H 館は約
表 2 ポピュラーライブラリーの構成

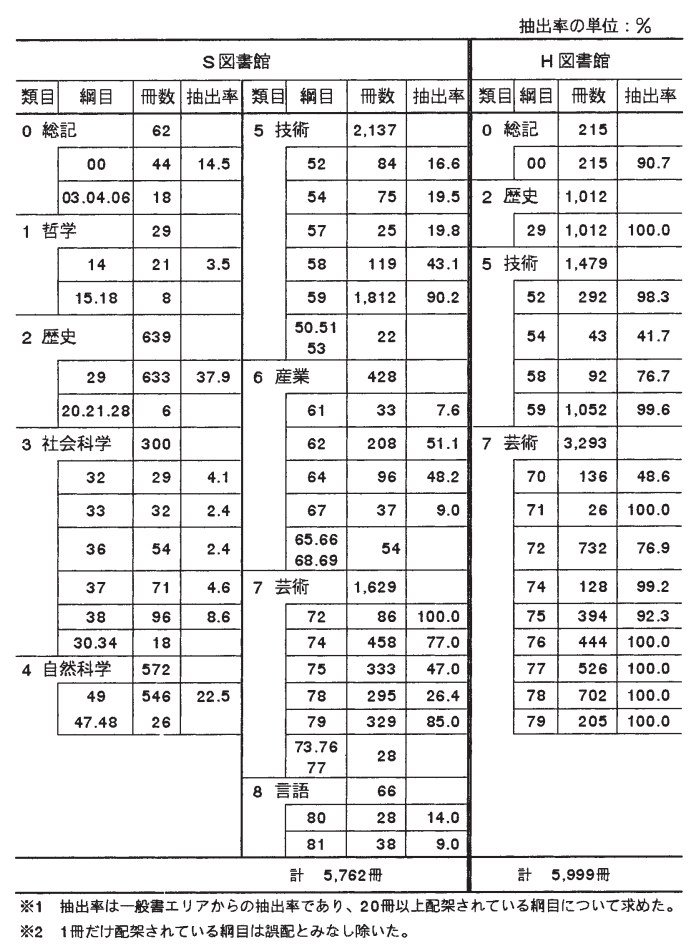

$42 \%$ と少なく、H 館では兄弟 2 人が $\mathrm{S}$ 館より約 $17 \%$ 多い注 8$)$ 。尚、以 下集計したデー夕は家族単位ではなく、個人単位である。

\section{2. ファミリーの利用型}

既編2）3）で報告した図書館利用（以下、一般図書館利用注9)）にお ける子ども全体の分離利用率は約 54\%であるのに比し（図 3)、S 館 約 67\%、H 館約 73\% と両館ともかなり高く、Active ゾーンを形成す ると、互いの主目的利用を果たすための分離利用が行われやすいと いえる。学年段階でみると、一般図書館において幼児は約 $36 \%$ 、小 低学年約 $64 \%$ 、小高学年約 $87 \%$ と学年段階があがるにつれ分離利用 は增える注10)。これに対し、S 館では幼児約 45\%、小低学年約 79\%と 一般図書館より高く、小高学年はやや下がる。H 館は幼児が約 $63 \%$ と S 館よりさらに高いのが特徵的で、小低学年と小高学年は S 館と そうかわらない。 H 館の幼児が高いのは、兄弟の利用が多いため分 離利用率が高くなったものと考えられる注11)。小高学年は一般の図書

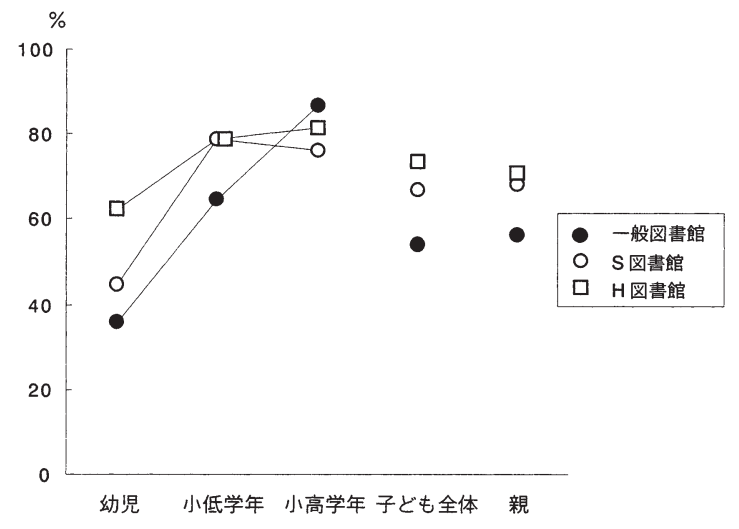

図3 分離利用率

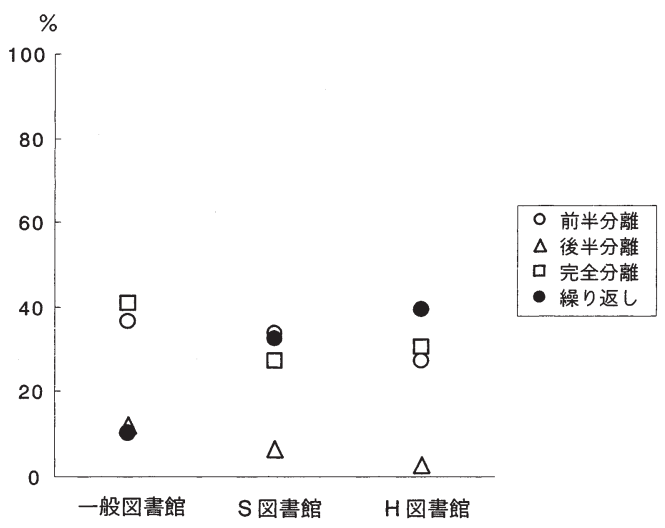

図4 分離利用型構成 

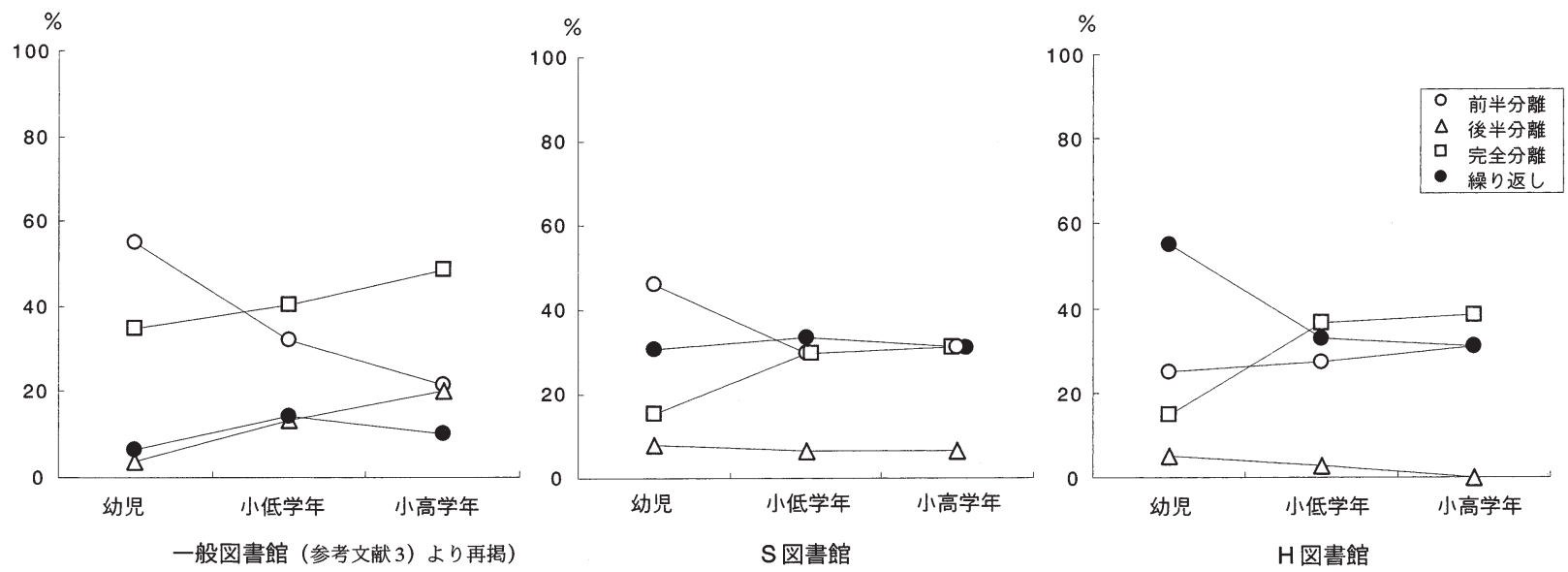

図 5 学年段階毎の分離利用型構成

館でも分離利用率は高く、この学年段階は空間構成に左右されずに 分離利用ができるためであろう。いずれにしても、Activeゾーンを 有する図書館では、幼児や小低学年で子どもと親が互いの主目的利 用のために分離する利用が多くなるといえる。

ファミリーの利用型をみると、付き添い利用はく子主体-親付き添 い>型と＜交互付き添い＞型がほとんどで、＜親主体-子つきまとい $>$ 型は $\mathrm{S}$ 館の 1 例のみである。一般図書館における分離利用は、< 前半分離 $>$ 型と $<$ 完全分離 $>$ 型が多 $<$ (図 4)、<後半分離 $>$ 型と $<$ 繰り返し > 型は少ない。これに対し、 $\mathrm{S}$ 館は＜前半分離 $>$ 型、<後半 分離 $>$ 型、<完全分離 $>$ 型いずれも少なくなり、<繰り返し $>$ 型が 約 $32 \%$ と一般図書館の 3 倍にもなる。 $\mathrm{H}$ 館も同様であり、この<繰 り返し>型は一般図書館の約 4 倍にもなる。つまり、一般図書館で は<前半分離 $>$ 型やく完全分離 $>$ 型になっていた利用が、分離と付 き添いがしやすいためにそれらを繰り返した結果、<繰り返し>型 が多くなったものと考えられ、Active ゾーンを有する図書館の特徵 である注12)。学年段階でみると（図 5)、一般図書館における幼児はく 前半分離 $>$ 型が多く、高学年になるにつれ<完全分離 $>$ 型が多くな るという学年段階による分離利用の変化がみられた。これに対し、 両館とも小低学年と小高学年の違いは小さく、いずれも<後半分離 $>$ 型を除く三つが同程度である。幼児においてもく繰り返し>型が 多いのは同じであるが、両館に共通して<完全分離 $>$ 型がかなり少 なく、その分 $\mathrm{S}$ 館は＜前半分離＞型が、 $\mathrm{H}$ 館は＜繰り返し＞型が多 い。H 館は Active ゾーンの規模が小さく、親の居場所がより身近で 行き来しやすいために<繰り返し>型が多くなったと考えられる。 いずれにしても、Activeゾーンはそれぞれの主目的利用を達成でき るエリアが近くにあるために、どの学年段階も必要に応じて分離と 付き添いを繰り返すことができ、逆に、それがお互いの主目的利用 を促していることになる。

\section{3. 主目的利用の内容}

そこで、主目的利用の種別利用型構成をみると（表 4)、種類毎の 資料が充実している S 館は、成人の単独利用やファミリ一利用の親 以上に子どもは複合利用が多く、しかも、ほとんどが $\mathrm{AB}$ 型、 $\mathrm{AV}$ 資 料と書籍 (主に児童書) 注13) の複合利用である。単種利用はほとん どが $\mathrm{B}$ 型、書籍だけの利用であり、 $\mathrm{AV}$ 資料だけの利用は少ない。こ れに対し、AV資料の種類と数に難がある $\mathrm{H}$ 館は、利用のほとんどは B 型、書籍だけの利用である。したがって、子どもは書籍の単種利
表 4 種別利用型

\begin{tabular}{|c|c|c|c|c|c|c|c|c|c|c|c|c|c|}
\hline \multirow{3}{*}{\multicolumn{2}{|c|}{ 利用型 }} & \multicolumn{4}{|c|}{ 子ども } & \multicolumn{4}{|c|}{ 親 } & \multicolumn{4}{|c|}{ 成人単独利用 } \\
\hline & & \multicolumn{2}{|c|}{ S図書館 } & \multicolumn{2}{|c|}{ H図書館 } & \multicolumn{2}{|c|}{ S図書館 } & \multicolumn{2}{|c|}{ H図書館 } & \multicolumn{2}{|c|}{ S図書館 } & \multicolumn{2}{|c|}{ H図書館 } \\
\hline & & 人数 & (\%) & 人数 & (\%) & 人数 & $(\%)$ & 人数 & $(\%)$ & 人数 & (\%) & 人数 & $(\%)$ \\
\hline 凟料利用なし & O型 & 2 & 2.3 & 0 & & 10 & 14.5 & 11 & \begin{tabular}{|l|}
17.7 \\
\end{tabular} & \begin{tabular}{|l|}
11 \\
\end{tabular} & 9.6 & 10 & 9.0 \\
\hline \multirow[t]{4}{*}{ 単種利用 } & A型 & 4 & 4.5 & 0 & & 5 & 7.2 & 0 & & 7 & 6.1 & 1 & 0.9 \\
\hline & B型 & 27 & 30.7 & 88 & 97.8 & 16 & 23.2 & 16 & 25.8 & \begin{tabular}{|l|}
30 \\
\end{tabular} & 26.3 & 34 & 30.6 \\
\hline & M型 & 0 & & 0 & & 9 & 13.0 & 9 & 14.5 & 16 & 14.0 & 15 & 13.5 \\
\hline & 小計 & 31 & 35.2 & 88 & 97.8 & 30 & 43.5 & 25 & 40.3 & 53 & 46.5 & 50 & 45.0 \\
\hline \multirow[t]{5}{*}{ 複合利用 } & $\mathrm{AB}$ 型 & 36 & 40.9 & 0 & & 3 & 4.3 & 0 & & 6 & 5.3 & 1 & 0.9 \\
\hline & BM型 & 4 & 4.5 & 2 & 2.2 & 20 & 29.0 & 25 & 40.3 & \begin{tabular}{|l|l|}
34 \\
\end{tabular} & 29.8 & 50 & 45.0 \\
\hline & AM 型 & 0 & & 0 & & 2 & 2.9 & 0 & & 1 & 0.9 & 0 & \\
\hline & ABM型 & 15 & 17.0 & 0 & & 4 & 5.8 & 1 & 1.6 & 9 & 7.9 & 0 & \\
\hline & 小計 & 55 & 62.5 & 2 & 2.2 & 29 & 42.0 & 26 & 42.0 & 50 & 43.9 & 51 & 45.9 \\
\hline \multicolumn{2}{|c|}{ 合計 } & 88 & 100.0 & 901 & 100.0 & 69 & 100.0 & & 00.0 & \begin{tabular}{l|l|}
114 & 1 \\
\end{tabular} & 100.0 & 111 & 100.0 \\
\hline
\end{tabular}

用か、 $\mathrm{AV}$ 資料が充実していれば書籍との複合利用になると考えてよ い。ちなみに、 $\mathrm{S}$ 館について $\mathrm{AB}$ 系複合利用比 ( $\mathrm{AB}$ 型数 $+\mathrm{ABM}$ 型数 の合計 $/ \mathrm{B}$ 型数 $+\mathrm{BM}$ 型数の合計）は 1.65 であり、成人の単独利用が

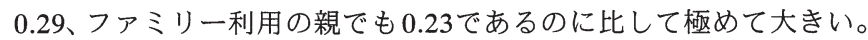
一方、親の種別利用型をみると、親の主目的利用がないく子主体-親 付き添い>型 (O型) 注14) があるため、それ以外の型は両館とも成人 の単独利用より構成割合は低くなる。しかし、単種利用で B 型が多 い点や複合利用は $\mathrm{BM}$ 型が中心となる点において成人の単独利用と 同様である。そこで、 $\mathrm{BM}$ 系複合利用比 (BM型数+ABM型数の合計/ $\mathrm{B}$ 型数 $+\mathrm{AB}$ 型数の合計)をみると、成人の単独利用では、一般書エリ アと新聞・雑誌エリアの隣接型の 1.14 より、 $\mathrm{S}$ 館は 1.19、 $\mathrm{H}$ 館は 1.43 と大きかったが注15)、ファミリ一利用の親は $\mathrm{S}$ 館が 1.26、H 館は 1.63 とさらに大きくなっており、Active ゾーンを有する図書館は、書籍 を利用する親において、成人の単独利用以上に新聞・雑誌との複合 利用を促進しているといえる。

\section{4. 親の利用書籍}

次に、書籍利用に注目すると、前編 ${ }^{6)}$ の成人の単独利用は一般書 の利用が約 71〜 $88 \%$ とメインであるが、一方でポピュラーブックの 利用は $40 \%$ にもなる（表 5)。これに対し、ファミリー利用の親は、 両館ともポピュラーブックの利用が成人の単独利用より $25 \%$ 前後も 増え (表 6)、実に約 $63 \sim 69 \%$ となり、成人の単独利用以上にポピュ ラーライブラリーエリアを設ける意義は大きい。しかし一方で、一 般書利用も約 60 〜 $62 \%$ あ。つまり、ポピュラーライブラリーを設 けてもその利用だけに特化してしまうわけではない。しかも、成人 の単独利用で多かったS館の一般書利用は約 $28 \%$ も減っているため、 両館の差は小さい。したがって、ポピュラーブックと一般書の利用 の仕方が問題となる。成人の単独利用では、この利用の仕方はポ 
ピュラーライブラリー構成方式により異なり、<多類目抽出 $>$ 方式 では一般書とポピュラーブックをともに利用する併用利用が多く、 <特定綱目一括＞方式では一般書のみかポピュラーブックのみの利 用が多くなる傾向がみられた注16)。そこで、利用した書籍の組合せを みると、当然、成人の単独利用に比べ一般書のみの利用（表中、 $\mathrm{B} の$ み）が減り、ポピュラーブックのみの利用（表中、Pのみ）が増える が、 $\mathrm{H}$ 館では成人の単独利用では少なかった併用利用（表中、 $\mathrm{B}+\mathrm{P}$ ) が増え、結果的に、両館に共通して、一般書のみを利用する、ポピュ ラーブックのみを利用する、あるいはその両方を利用する、という 三つの利用の仕方がそう変わらずに併存する形である。つまり、ポ ピュラーライブラリーの構成方式の差異は小さく、ここに成人の単 独利用との違いが窅われる。三つの利用の仕方を抽出すると、一般 書（B）のみの利用：一般書のみの利用は約 $31 \sim 37 \%$ あ、ポピュ ラーライブラリーがあろうと影響されない、つまり、もともと綱目 59 やそれ以外の多類目・特定綱目を蒐集した「暮らしと生活」といっ た構成が対象でない利用である。ポピュラーブック $(P)$ のの利用 : ポピュラーライブラリーで満足し得る、つまり、ポピュラーライブ ラリーの設定が直接的に寄与した利用であり、 $40 \%$ 近くにのぼる。 しかも、<多類目抽出>方式の S 館でも単独利用時に比べて約 $28 \%$ も増え $\mathrm{H}$ 館とかわらないことから、両方の構成方式に共通した綱目 59 の書籍が主対象と考えられ、今回の事例では母親が圧倒的に多い ためであろう注17)。一般書とポピュラーブックの併用 (B+P) 利用 : 成人の単独利用において<多類目抽出 $>$ 方式の $\mathrm{S}$ 館では一般書への 橋渡しとみられた利用であるが、<特定綱目一括 >方式の $\mathrm{H}$ 館で 3 割を越えていることから、ポピュラーブックは対象でありつつも同 時にそれ以外の対象がある利用と考えてよい。

ファミリ一利用型毎にみると、付き添い利用、これは主にく交互 付き添い>型であるが、 $\mathrm{S}$ 館は B のみ、 $\mathrm{H}$ 館は $\mathrm{B}$ のみか $\mathrm{P}$ のみであり、 この型では親は一般書の利用が多く、児童書エリア利用の後、離れ たQuietゾーンを利用するために子どもはつきまとわざるを得ない状 況にあったと考えられる。分離利用においてはポピュラーブックの 比重が高まるが、先ほどみた両館の全体傾向と大差なく数が多いこ とから、先ほどの傾向は分離利用により生じていると考えてよい。 利用型でいえば、<前半分離 $>$ 型や<後半分離 $>$ 型は分離している 時間が短いため $\mathrm{B}$ か $\mathrm{P}$ のみが多いが、<完全分離 > 型やく繰り返し $>$ 型は分離時間も相対的に長くなるためか $\mathrm{B}$ のみは少なく、前二者 に比べ B+Pが多い傾向にある。つまり、利用対象が利用型を決める 一要因になっている。

いずれにしても、ファミリ一利用の親においてポピュラーライブ ラリーエリアの存在意義は大きいが、一方で、ポピュラーブックの みの利用に限定されない、言い換えると、Activeゾーンにポピュラー ライブラリーエリアを設けても、そのゾーン内で親の書籍利用は完 結するわけではない。

\section{5. 滞在時間}

子どもと親が同伴して来退館したファミリ一を対象としたため、 子どもと親の滞在時間はほとんどかわらず、 $\mathrm{S}$ 館の子どもは約 31 分、 $\mathrm{H}$ 館の子どもは約 30 分と図書館の差も小さい（表 7、表 8)。成人の 単独利用時と親の滞在時間を比較すると、 $\mathrm{H}$ 館では成人単独利用は かなり長い滞在であったにも関わらず親の滞在時間は短くなり、両
表 5 成人単独の利用書籍 (参考文献6) より再揭)

\begin{tabular}{|c|c|c|c|c|c|c|c|c|}
\hline \multirow{2}{*}{ 利用型 } & \multicolumn{4}{|c|}{ S図書館 } & \multicolumn{4}{|c|}{ H図書館 } \\
\hline & Bのみ & $B+P$ & Pのみ & 計 & Bのみ & $B+P$ & Pのみ & 計 \\
\hline \multirow{3}{*}{$\begin{array}{c}\text { 成人の } \\
\text { 単独利用合計 }\end{array}$} & 47 & 20 & 9 & 76 & 44 & 11 & 22 & 77 \\
\hline & (61.9) & $(26.3)$ & $(11.8)$ & $(100.0)$ & $(57.1)$ & $(14.3)$ & $(28.6)$ & $(100.0)$ \\
\hline & B利用三 & \multicolumn{2}{|c|}{ P利用者 29 人、38.2\% } & & & \multicolumn{3}{|c|}{ P利用者 33 人、 $42.9 \%$} \\
\hline
\end{tabular}

表 6 親の利用書籍

\begin{tabular}{|c|c|c|c|c|c|c|c|c|c|}
\hline \multirow{2}{*}{\multicolumn{2}{|c|}{ 利用型 }} & \multicolumn{4}{|c|}{ S図畫館 } & \multicolumn{4}{|c|}{ H図書館 } \\
\hline & & Bのみ & $B+P$ & Pのみ & 計 & Bのみ & $B+P$ & Pのみ & 計 \\
\hline & B型 & $\begin{array}{r}6 \\
(37.5)\end{array}$ & $\begin{array}{r}2 \\
(12.5) \\
\end{array}$ & $\begin{array}{r}8 \\
(50.0) \\
\end{array}$ & $\begin{array}{r}16 \\
(100.0)\end{array}$ & $\begin{array}{r}7 \\
(43.8) \\
\end{array}$ & $\begin{array}{r}5 \\
(31.2) \\
\end{array}$ & $\begin{array}{r}4 \\
(25.0) \\
\end{array}$ & $\begin{array}{r}16 \\
(100.0) \\
\end{array}$ \\
\hline & $\mathrm{AB}$ 型 & $\begin{array}{r}1 \\
(33.3)\end{array}$ & $\begin{array}{r}1 \\
(33.3)\end{array}$ & $\begin{array}{r}1 \\
(33.3)\end{array}$ & $\begin{array}{r}3 \\
(100.0)^{3}\end{array}$ & & & & \\
\hline & BM型 & $\begin{array}{r}6 \\
(30.0)\end{array}$ & $\begin{array}{r}7 \\
(35.0)\end{array}$ & $\begin{array}{r}7 \\
(35.0)\end{array}$ & $\begin{array}{r}20 \\
(100.0)\end{array}$ & $\begin{array}{r}5 \\
(20.0)\end{array}$ & $\begin{array}{r}8 \\
(32.0) \\
\end{array}$ & $\begin{array}{r}12 \\
(48.0) \\
\end{array}$ & $\begin{array}{r}25 \\
(100.0)\end{array}$ \\
\hline & $\mathrm{ABM}$ & $\begin{array}{r}3 \\
(75 .)^{3} \\
\end{array}$ & & $\begin{array}{r}1 \\
(25.0) \\
\end{array}$ & $\begin{array}{r}4 \\
(100.0) \\
\end{array}$ & \begin{tabular}{|r|}
1 \\
$(1000.0)$ \\
\end{tabular} & & & $\begin{array}{r}1 \\
(100.0) \\
\end{array}$ \\
\hline & $\begin{array}{r}16 \\
(37.2) \\
\end{array}$ & $\begin{array}{r}10 \\
(23.3)\end{array}$ & $\begin{array}{r}17 \\
(39.5)\end{array}$ & $\begin{array}{r}43 \\
(100.0)\end{array}$ & $\begin{array}{r}13 \\
(31.0)\end{array}$ & $\begin{array}{r}13 \\
(31.0)\end{array}$ & $\begin{array}{r}16 \\
(38.0)\end{array}$ & $\begin{array}{r}42 \\
(100.0)\end{array}$ \\
\hline & & \multicolumn{4}{|c|}{ B利用者 26 人、 $60.3 \%$} & & \multicolumn{2}{|c|}{ B利用者 26 人、61.9\% } & \\
\hline & $\begin{array}{c}\text { き添い利用 } \\
\text { 合計 }\end{array}$ & $\begin{array}{r}5 \\
(62.5) \\
\end{array}$ & $\begin{array}{r}2 \\
(25.0) \\
\end{array}$ & $\begin{array}{r}1 \\
(12.5)\end{array}$ & $\begin{array}{r}8 \\
(100.0)\end{array}$ & $\begin{array}{r}2 \\
(50.0) \\
\end{array}$ & . & $\begin{array}{r}2 \\
(50.0) \\
\end{array}$ & $\begin{array}{r}4 \\
(100.0) \\
\end{array}$ \\
\hline & 離利用合計 & $\begin{array}{r}11 \\
(31.4)\end{array}$ & $\begin{array}{r}8 \\
(22.9)\end{array}$ & $\begin{array}{r}16 \\
(45.7)\end{array}$ & $\begin{array}{r}35 \\
(100.0)\end{array}$ & $\begin{array}{r}11 \\
(28.9)\end{array}$ & $\begin{array}{r}13 \\
(34.2) \\
\end{array}$ & $\begin{array}{r}14 \\
(36.8)\end{array}$ & $\begin{array}{r}38 \\
(100.0)\end{array}$ \\
\hline 内 & $\begin{array}{l}\text { 前半分離+ } \\
\text { 後半分離 }\end{array}$ & $\begin{array}{r}6 \\
(46.2) \\
\end{array}$ & $\begin{array}{r}2 \\
(15.4) \\
\end{array}$ & $\begin{array}{r}5 \\
(38.5)\end{array}$ & $\begin{array}{r}13 \\
(100.0) \\
\end{array}$ & $\begin{array}{c}4 \\
(36.4) \\
\end{array}$ & $\begin{array}{r}2 \\
(18.2) \\
\end{array}$ & $\begin{array}{r}5 \\
(45.5) \\
\end{array}$ & $\begin{array}{c}11 \\
(100.0)\end{array}$ \\
\hline & $\begin{array}{l}\text { 完全分離+ } \\
\text { 繰り返し }\end{array}$ & $\begin{array}{r}5 \\
(22.7)\end{array}$ & $\begin{array}{r}6 \\
(27.3)\end{array}$ & $\begin{array}{c}11 \\
(50.0)\end{array}$ & $\begin{array}{r}22 \\
(100.0)\end{array}$ & $\begin{array}{c}7 \\
(26.0)\end{array}$ & $\begin{array}{c}11 \\
(40.7)\end{array}$ & $\begin{array}{c}9 \\
\text { (з3.3) }\end{array}$ & $\begin{array}{r}27 \\
(100.0)\end{array}$ \\
\hline
\end{tabular}

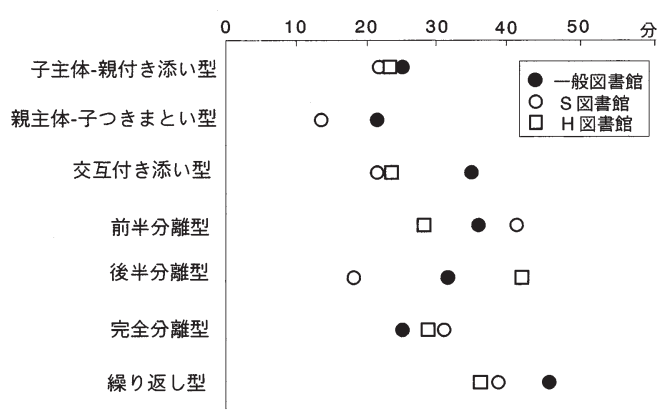

図 6 利用型毎の滞在時間

館とも $\mathrm{S}$ 館の成人単独利用の滞在時間とそう変わらない。以下、子 どもの滞在時間で分析を進める。

分離利用と付き添い利用でみると、分離利用は約 $32 \sim 36$ 分と両 館とも共通的で全体の滞在時間とそう変わらないが、付き添い利用 は約 $21 〜 23$ 分と両館とも共通的に約 10 分ほど短い(表7、表 8 )。そ こで、ファミリーの利用型でみると（図 6)、付き添い利用は、1例 しかないく親主体-子つきまとい>型を除くと両館の違いは小さく、 〈子主体-親付き添い>型は一般図書館のそれとかわらないが、それ ぞれの主目的利用を満たすために時間が長いのが特徴的であったく 交互付き添い>型は、両館とも一般図書館のそれよりかなり短い。 したがって、この型は、子どもか親のいずれかあるいは両方の主目 的利用の時間が短いことになるが、その分析は次章にゆずる。分離 利用は、<前半分離 $>$ 型と<後半分離 $>$ 型で両館の差が大きい。< 前半分離 $>$ 型は同伴した兄弟の学年段階が異なることが影響してい ると考えられ注18)、《後半分離>型は事例数が少ないうえに注19)、S 館 は $3 / 4$ の事例が利用時間が短い $\mathrm{AV}$ 資料の選択であり、滞在時間が短 くなったものである。いずれにしても、Active ゾーンを形成した図 書館として両館を平均すると、二つの利用型とも一般図書館のそれ とそう変わらないことになる。＜完全分離＞型と＜繰り返し＞型は 
表 $7 \mathrm{~S}$ 図書館のエリア別利用人数・時間

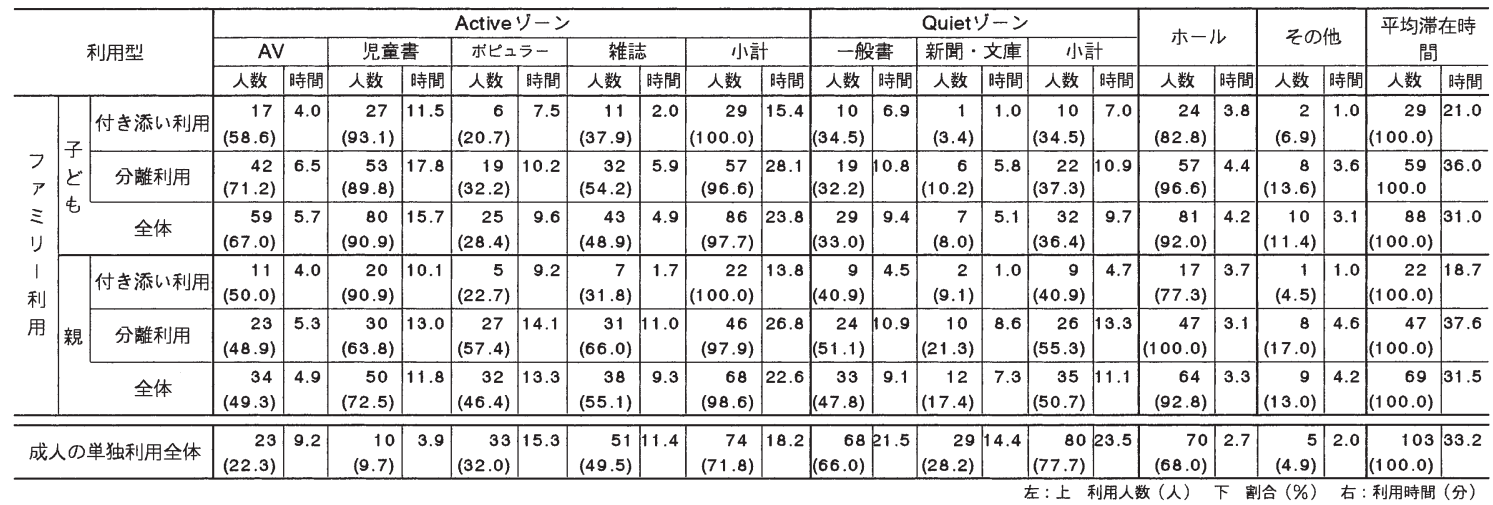

表 $8 \mathrm{H}$ 図書館のエリア別利用人数・時間

\begin{tabular}{|c|c|c|c|c|c|c|c|c|c|c|c|c|c|c|c|c|c|c|c|c|c|c|c|c|}
\hline & \multirow{3}{*}{\multicolumn{2}{|c|}{ 利用型 }} & \multicolumn{10}{|c|}{ Active ソーン } & \multicolumn{6}{|c|}{ Quietゾーン } & \multirow{2}{*}{\multicolumn{2}{|c|}{ ホール }} & \multirow{2}{*}{\multicolumn{2}{|c|}{ その他 }} & \multirow{2}{*}{\multicolumn{2}{|c|}{$\begin{array}{c}\text { 平均滞在時 } \\
\text { 間 }\end{array}$}} \\
\hline & & & \multicolumn{2}{|c|}{ AV } & \multicolumn{2}{|c|}{ 児童書 } & \multicolumn{2}{|c|}{ 术ヒュラー } & \multicolumn{2}{|c|}{ 新䦪-稚㰴 } & \multicolumn{2}{|c|}{ 小計 } & \multicolumn{2}{|c|}{ 一般書 } & \multicolumn{2}{|c|}{ 文庫 } & \multicolumn{2}{|c|}{ 小計 } & & & & & & \\
\hline & & & 人数 & \begin{tabular}{|l|} 
時間 \\
\end{tabular} & 人数 & 時間 & 人数 & |時間 & 人数 & 時間 & 人数 & \begin{tabular}{|l|} 
時間 \\
\end{tabular} & 人数 & 時間 & 人数 & 時間 & 人数 & \begin{tabular}{|l|} 
時間 \\
\end{tabular} & 人数 & |時間 & 人数 & |時間 & 人数 & \begin{tabular}{|l|} 
時間 \\
\end{tabular} \\
\hline \multirow{6}{*}{$\begin{array}{c}\text { 1 } \\
\text { 利 } \\
\text { 用 }\end{array}$} & \multirow{3}{*}{$\begin{array}{l}\text { ど } \\
\text { 屯 }\end{array}$} & 付き添い利用 & $\begin{array}{r}1 \\
(4.2) \\
\end{array}$ & 1.0 & $\begin{array}{c}24 \\
(100.0) \\
\end{array}$ & 17.1 & $\begin{array}{r}3 \\
(12.5) \\
\end{array}$ & 1.0 & $\begin{array}{r}3 \\
(12.5) \\
\end{array}$ & \begin{tabular}{|l|l} 
\\
\end{tabular} & $\begin{array}{c}24 \\
(100.0) \\
\end{array}$ & \begin{tabular}{|l|}
17.4 \\
\end{tabular} & $\begin{array}{c}4 \\
(16.7) \\
\end{array}$ & 7.8 & & & \begin{tabular}{|c|}
6 \\
$(25.0)$ \\
\end{tabular} & 5.2 & $\begin{array}{c}21 \\
(87.5) \\
\end{array}$ & 4.8 & $\begin{array}{c}2 \\
(8.3) \\
\end{array}$ & 3.8 & $\begin{array}{c}24 \\
(100.0) \\
\end{array}$ & 23.2 \\
\hline & & 分離利用 & $\begin{array}{r}1 \\
(1.5) \\
\end{array}$ & 1.0 & $\begin{array}{c}66 \\
(100.0) \\
\end{array}$ & 23.8 & $\begin{array}{c}24 \\
(36.4) \\
\end{array}$ & 4.2 & $\begin{array}{c}11 \\
(16.7) \\
\end{array}$ & 2.0 & $\begin{array}{c}66 \\
(100.0) \\
\end{array}$ & 25.7 & $\begin{array}{c}18 \\
(27.3) \\
\end{array}$ & 4.4 & $\begin{array}{c}1 \\
(1.5) \\
\end{array}$ & 4.0 & $\begin{array}{r}18 \\
(27.3) \\
\end{array}$ & 4.6 & \begin{tabular}{|c|}
63 \\
$(95.5)$ \\
\end{tabular} & 4.7 & \begin{tabular}{|c|}
9 \\
$(13.6)$ \\
\end{tabular} & 3.2 & $\begin{array}{c}66 \\
(100,0) \\
\end{array}$ & 31.9 \\
\hline & & 全体 & $\begin{array}{r}2 \\
(2.2) \\
\end{array}$ & 1.0 & $\begin{array}{c}90 \\
(100.0) \\
\end{array}$ & 22.0 & $\begin{array}{c}27 \\
(30.0) \\
\end{array}$ & 3.9 & $\begin{array}{c}14 \\
(15.6) \\
\end{array}$ & 1.8 & $\begin{array}{r}90 \\
(100.0) \\
\end{array}$ & 23.5 & $\begin{array}{r}22 \\
(24.4) \\
\end{array}$ & 5.0 & $\begin{array}{c}1 \\
(1.1) \\
\end{array}$ & 4.0 & $\begin{array}{r}24 \\
(26.7) \\
\end{array}$ & 4.8 & \begin{tabular}{|c|}
84 \\
$(93.3)$ \\
\end{tabular} & 4.8 & $\begin{array}{c}11 \\
(12.2) \\
\end{array}$ & 3.3 & $\begin{array}{r}90 \\
(100.0) \\
\end{array}$ & 29.6 \\
\hline & \multirow{3}{*}{ 親 } & 付き添い利用 & & & $\begin{array}{c}18 \\
(100.0)\end{array}$ & 16.8 & $\begin{array}{r}3 \\
(16.7) \\
\end{array}$ & 1.5 & $\begin{array}{r}4 \\
(22.2) \\
\end{array}$ & 1.0 & $\begin{array}{r}18 \\
(100.0)\end{array}$ & 17.3 & \begin{tabular}{|c|}
4 \\
$(22.2)$ \\
\end{tabular} & 3.4 & $\begin{array}{r}1 \\
(5.6) \\
\end{array}$ & 1.0 & $\begin{array}{r}4 \\
(22.2) \\
\end{array}$ & 3.6 & $\begin{array}{r}16 \\
(88.9) \\
\end{array}$ & 4.0 & \begin{tabular}{r|}
6 \\
$(33.3)$ \\
\end{tabular} & 5.0 & $\begin{array}{r}18 \\
(100.0) \\
\end{array}$ & $\begin{array}{l}323.3 \\
\end{array}$ \\
\hline & & 分離利用 & $\begin{array}{r}1 \\
(2.3) \\
\end{array}$ & 1.0 & $\begin{array}{r}35 \\
(79.5) \\
\end{array}$ & 15.1 & $\begin{array}{r}33 \\
(75.0) \\
\end{array}$ & 11.3 & $\begin{array}{c}29 \\
(65.9) \\
\end{array}$ & 3.8 & $\begin{array}{c}43 \\
(97.7) \\
\end{array}$ & 23.5 & $\begin{array}{c}21 \\
(47.7) \\
\end{array}$ & 11.6 & $\begin{array}{c}4 \\
(9.1) \\
\end{array}$ & 3.3 & $\begin{array}{r}21 \\
(47.7) \\
\end{array}$ & 12.2 & $\begin{array}{r}39 \\
(88.6) \\
\end{array}$ & 3.9 & $\begin{array}{r}11 \\
(25.0) \\
\end{array}$ & 6.5 & $\begin{array}{r}44 \\
(100.0) \\
\end{array}$ & $\begin{array}{l}433.9 \\
\end{array}$ \\
\hline & & 全体 & $\begin{array}{r}1 \\
(1.6) \\
\end{array}$ & 1.0 & $\begin{array}{c}53 \\
(85.5) \\
\end{array}$ & 15.7 & $\begin{array}{r}36 \\
(58.1) \\
\end{array}$ & 10.5 & $\begin{array}{r}33 \\
(53.2) \\
\end{array}$ & 3.4 & $\begin{array}{r}61 \\
(98.4) \\
\end{array}$ & 21.7 & $\begin{array}{r}25 \\
(40.3) \\
\end{array}$ & 10.3 & $\begin{array}{r}5 \\
(8.1) \\
\end{array}$ & 2.8 & $\begin{array}{r}25 \\
(40.3) \\
\end{array}$ & 10.8 & $\begin{array}{r}55 \\
(88.7) \\
\end{array}$ & 3.9 & $\begin{array}{r}17 \\
(27.4)\end{array}$ & 5.9 & $\begin{array}{r}62 \\
(100.0) \\
\end{array}$ & \begin{tabular}{|l|l|}
2 & 30.8 \\
\end{tabular} \\
\hline & 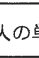 & 単独利用全体 & $\begin{array}{r}2 \\
(2.0) \\
\end{array}$ & 2.0 & $\begin{array}{r}18 \\
(17.8) \\
\end{array}$ & 28.0 & $\begin{array}{r}50 \\
(49.5) \\
\end{array}$ & 30.4 & $\begin{array}{r}62 \\
(61.4) \\
\end{array}$ & 3.1 & $\begin{array}{r}75 \\
(74.3) \\
\end{array}$ & 29.6 & $\begin{array}{r}62 \\
(61.4)\end{array}$ & 33.6 & \begin{tabular}{|r|}
10 \\
$(9.9)$ \\
\end{tabular} & 6.0 & $\begin{array}{r}63 \\
(62.4) \\
\end{array}$ & 34.0 & \begin{tabular}{|r|}
56 \\
$(55.4)$ \\
\end{tabular} & 1.7 & \begin{tabular}{r|}
22 \\
$(21.8)$ \\
\end{tabular} & 5.0 & $\begin{array}{r}101 \\
(100.0) \\
\end{array}$ & \begin{tabular}{|l|l|}
15.3 \\
\end{tabular} \\
\hline
\end{tabular}

両館の差は小さく、共通して、一般図書館と比べく完全分離＞型は やや長くなり、逆に<繰り返し>型はかなり短くなっている。2 章に おいてく繰り返し>型が多くなったこととあわせて考えると、一般 図書館では＜前半分離 $>$ 型やく完全分離 $>$ 型になっていた利用のう ち、比較的滞在時間が短い利用がく繰り返し>型に移行したため、 $\mathrm{S} \cdot \mathrm{H}$ 館の<繰り返し>型は滞在時間が短くなったと解釈できる。

\section{6. ゾーン別、エリア別の利用状況}

S 館についてみると（表 7)、子ども全体では、ほとんどが Active ゾーンを利用し、平均滞在時間 31 分に対して約 24 分を費やしてい る。ゾーン内では、児童書エリアと AVエリアは約 91、67\%の者が 約 16、6 分利用し、この二つが利用の中心であるが、そればかりで なく、ポピュラーライブラリーエリアや雑誌エリアをそれぞれ約 28 、 $49 \%$ が約 10、5 分利用している。一方、約 10 分と短いものの約 $36 \%$ がQuietゾーン、主に一般書エリアを利用している。付き添い利用は、 <子主体-親付き添い>型と<交互付き添い>型が半々で、滞在時間 は約 21 分と短いが Active ゾーン内を約 15 分利用し、主に児童書工 リアと AVエリアであるが、人数は子ども全体と同程度で、時間は 短かい。＜交互付き添い＞型はポピュラーライブラリーや雑誌エリ アに約 21、38\%が約 8、2 分、Quiet ゾーンでは一般書エリアに約 35 \%が約 7 分親に付きまとっている。これに対し、分離利用は、ほと んどの者がActiveゾーンを利用し時間は約 28 分と付き添い利用より 約 13 分も長い。児童書エリアの利用人数はそう変わらずに時間が約 6 分長いためであるが、一方で、AVエリア以外にもポピュラーライ ブラリーエリアや雑誌エリアのいずれも付き添い利用より利用人数 は多く、時間も長くなっており、必ずしも付き添い的立ち寄りとは
言い難い。そればかりかQuietゾーンの一般書エリアの利用は、人数 は約 $32 \%$ で主に小高学年であるが、時間が約 11 分と付き添い利用よ り長くなっており、Activeゾーン内の各エリアはもちろんのこと、ー 般書エリアまで分散して活発に利用している。

親全体では、ほとんどの親が Active ゾーンを利用するが、半数は Quiet ゾーンを利用している。成人の単独利用と比較すると、Active ゾーンの利用人数はより多く、中でも児童書エリアの利用人数が約 73\%に及ぶのは当然としても、時間こそやや短かくなるものの、ポ ピュラーライブラリーエリアや雑誌エリアの利用人数はむしろ多い。 その分、Quietゾーンにおいては一般書エリアの利用時間は約 9 分と かなり短い。付き添い利用は、先述の子どもの付き添い利用と同じ 傾向であるが、一般書エリアの利用時間はさらに短い。特に<交互 付き添い>型は前章でみた如く一般の図書館より滞在時間が短か かったが、親の一般書利用の時間を短くして対処している。分離利 用は、子どもと違い、児童書エリアや AVエリアの利用人数はそれ ぞれ約 $64 、 49 \%$ と少なくなり、その分ポピュラーライブラリーエリ アや雑誌エリアの利用人数はそれぞれ約 $57 、 66 \%$ と成人の単独利用 よりかなり多く、しかも利用時間はそうかわらない。一方、Quietゾー ンの一般書エリアは利用人数は半数にのぼるが、利用時間は Active ゾーン内の各エリアの利用時間程度で、成人の単独利用に比べると 半分程度と短い。つまり、Active ゾーン内の各エリアを利用して時 間を費やしつつ、半数はそれでも短い時間で一般書エリアを利用し ている。このことは、先述の<交互付き添い>型でも同様であり、 $\mathrm{S}$ 館の親は、Quietゾーン、中でも一般書エリアの利用時間が短いこと が特徴的である。

H 館をみると（表 8)、子どもは全員が Active ゾーンの児童書エリ 
アを利用し、全体ではゾーンの利用時間約 24 分に対して約 22 分を 費やしている。そのため、座席がない新聞・雑誌エリアは立ち寄り 程度であるばかりでなく、ポピュラーライブラリーエリアも $30 \%$ 程 度は利用するが時間は約 4分とかなり短い。Quietゾーンにおいて一 般書エリアの利用人数は $\mathrm{S}$ 館より約 $10 \%$ 少なくなるが、特に利用時 間は半分とかなり短い。全体として、利用エリアは Active ゾーンの 児童書エリアに集中している。付き添い利用において一般書エリア の利用人数が少ないのは、<子主体 - 親付き添い>型が約 $3: 1$ と多 く<交互付き添い〉型が少ないためであり、利用時間は $\mathrm{S}$ 館と同程 度である。分離利用は、ポピュラーライブラリーエリアの利用人数 が約 $37 \%$ と S 館より多くなるが、時間は約 4 分と S 館の半分に満た ず、これは親のところに行っても、また、すぐに児童書エリアに戻 る者が多いためである。一般書エリアの利用は、利用人数は $\mathrm{S}$ 館と 同程度であるが、利用時間は $\mathrm{S}$ 館の半分以下である。ここに、ゾー ン配置の影響が考えられる。つまり、子どもと親が両ゾーンに別れ る分離利用の場合、S 館は Active ゾーンとQuietゾーンが中庭を挟む ものの視覚的には連続しているため、子どもは Active ゾーンの親と 離れても安心できるが、 $\mathrm{H}$ 館は両ゾーンが事務室等で分断され視覚 的連続性がないため、Active ゾーンの親と時間をかけて離れづらい ということになる。

親全体は、成人の単独利用よりも滞在時間が約 15 分も短いが、特 に、Quiet ゾーンの一般書エリアの利用時間が約 23 分も短いためで あり、利用人数も約 $20 \%$ 少なく、利用時間ともに $\mathrm{S}$ 館とそうかわら ない。Activeゾーン内では児童書エリアの利用人数は $\mathrm{S}$ 館より多く、 ポピュラーライブラリーエリアの利用人数も $\mathrm{S}$ 館同様成人の単独利 用時より約 $10 \%$ 増えるものの、時間は約 10 分と 20 分近くも短くな り、 $\mathrm{S}$ 館との差は小さい。付き添い利用は、子どもの付き添い利用の 傾向と同じであり、一般書エリアの滞在時間が短いのも $\mathrm{S}$ 館と同様 である。分離利用は、S 館より児童書エリアとポピュラーライブラ リーエリアの利用人数は約 $16 、 18 \%$ も多く、座席が配置されたこの 二つのエリアに集中していることがわかる。一般書エリアは $\mathrm{S}$ 館と 同程度の利用人数であり、時間もそう変わらず、〈交互付き添い> 型を含めやはり限られた短い時間で一般書エリアを利用している。

全体として、両館とも、子どもも親も Active ゾーン中心の利用で あること、しかし一方で、親の半数と子どもの 3 割前後は限られた 短い時間の中でQuietゾーンの一般書エリアを利用していることが特 徵的である。Active ゾーンの中では、分離利用において図書館によ り過ごすエリアが異なっている。S館では子どもは児童書エリアを中 心としつつ、他のAVエリア、雑誌エリア、ポピュラーライブラリー エリアに分散して滞在しており、親も AV エリアを除いて同様であ る。それに対し、H館では、子どもはほとんど児童書エリアにおり、 親もやはり児童書エリアを中心としつつ、ポピュラーライブラリー エリアに滞在するという構図である。このことは、Active ゾーンの 規模と各資料の充実度の違いの影響もあろうが、各エリアの座席配 置の影響が大きいと考えられる。というのも、 $\mathrm{H}$ 館は新聞・雑誌エ リアに座席がなく、かつ、児童書エリアと他のエリアとの座席比が $\mathrm{S}$ 館は約 $1: 1$ に対し、H 館は約 $2: 1$ と児童書エリアに集中している からである。また、Activeゾーンと Quietゾーンの配置構成は、子ど もの分離利用、特に親と離れたQuietゾーンの一般書エリア利用の時 間に影響している。

\section{7. 拠点利用}

前章の分離利用において、子どもはポピュラーライブラリーエリ アや雑誌エリアにおいてどう過ごしているかであるが、ここでは付 き添い読書利用に注目する。既編 3 )で、児童書エリアと一般書エリ アの隣接型では＜前半分離＞型において親の付き添い読書利用-分離 した後、親が一般書エリアで目的の本を探し、児童書エリアに戻り 子どもの傍らで本を読みながら見まもる利用-がみられ、この利用は 隣接型図書館だけにみられる特徵であることを指摘した。今回、逆 に子どもの付き添い読書利用-子どもが親の近くの座席について児童 書を読む一という利用もみられ、これらをまとめ拠点利用と呼ぶこと にする。すなわち、拠点利用は、子どもか親のどちらかがいるエリ アで合流した後も、近くの座席に座りそれぞれの主目的利用を継続 することである。この拠点利用は、両図書館ともく前半分離 $>$ 型と <繰り返し>型でみられ、S 館 14/39 例、H館 12/44 例と事例数もほ ぼ同じである。内訳は、どちらかが本を選んでいる横で付き添い読 書をするケースが 5 例あるが、多くは親子ともに付き添い読書をし ており、拠点の位置は、前章でみた如く Active ゾーン内の座席配置 で決まり、児童書エリアが最も多く（S 館 8 例、 H 館 7例)、ついで ポピュラーライブラリーエリア ( $\mathrm{S}$ 館 4 例、 $\mathrm{H}$ 館 5 例)、雑誌エリア （S 館 4 例）である。いずれにしろ、Active ゾーンは、親子が離れて は資料を探し、合流しては付き添いつつ各自の資料を読むという行 為を繰り返しやすい空間と言える。

\section{8. まとめ}

地域公共図書館の開架フロアについて、ポピュラーライブラリー を核にした Active ゾーンと Quietゾーンで構成された図書館利用の 特徴をファミリ一利用から明らかにし、この手法が親と子どもの分 離利用や親の書籍と新聞・雑誌との複合利用を促進する平面構成で あることを明らかにした。以下、要約する。

1) Active ゾーンと Quiet ゾーンで構成された図書館におけるファミ リ一利用は、子どもと親が互いの主目的利用を行うために分離する 利用が多く、特に、幼児・小低学年で顕著であり、親の付き添い利 用が多い幼児でも分離利用しやすい。この分離利用ではく繰り返し >型、子どもと親が離れては付き添うの繰り返しが多いことが特徵 的であり、これは、程度の差こそあれどの学年段階でも多くみられ る。

2) 子どもが利用する資料は AV 資料と書籍がほとんどであり、AV 資料が充実すれば書籍との複合利用が多くなる。また、書籍を利用 する親も成人の単独利用以上に新聞・雑誌との複合利用が促進され る。

3）親が利用する書籍はポピュラーブックの利用が 7 割近くにのぼ り、成人の単独利用以上にポピュラーライブラリーエリアを設ける 意義は大きい。その利用は、母親の同伴が多い場合には綱目 59 が主 対象となるため、ポピュラーライブラリーの構成方式の影響は少な いが、一方で、綱目 59 だけに主対象がない場合もあるため、一般書 の利用も 6 割程度あり、多くは限られた短い時間で一般書エリアを 利用する。

4) 滞在エリアはActiveゾーン内が中心であり、ほとんどの子どもと 親は主に児童書エリアを利用し利用時間も長い。子どもは他に AV エリアの利用も多いが、親は分離利用により、ポピュラーライブラ 
リーエリアや新聞・雑誌エリアにも多くが滞在する。一方、Active ゾーン内の各エリアの座席配置が充実すれば、子どもは各エリアに 分散して滞在する。それは、分離利用で多いく繰り返し>型におい て、書籍の選択と付き添い読書を繰り返す拠点利用がみられるから であり、Activeゾーンを形成した図書館の大きな特徵である。

\section{Active ゾーンを形成した図書館利用の特徵}

前編6) の成人単独利用とあわせて Activeゾーンを形成した図書館 利用の特徴をまとめると、

1) 成人は単独利用であれファミリー利用であれ、書籍利用者におい て新聞・雑誌との複合利用が促進される。その書籍利用において、ポ ピュラーブックの利用は成人の単独利用で約 4 割、ファミリ一利用 の親で実に6〜7割にも及び、ポピュラーライブラリーエリアを設け る意義は大きい。このポピュラーライブラリーの構成方式は、単独 で利用する成人の一般書エリア利用に影響するが、ファミリ一利用 の親は特に母親のように綱目 59 が主対象になる場合は、構成方式の 影響は少ない。

2)上述の如くポピュラーライブラリーの構成方式によっても異なる が、成人の単独利用では Active ゾーンと Quiet ゾーン（とりわけ一 般書エリア）の利用はおおまかにはどちらも半数程度以上になる。 一方、ファミリー利用はほとんどの子どもと親が Active ゾーンを利 用し、中でも児童書エリアが利用の中心となり、Quietゾーンの利用 は人数も時間も半減する。この Active ゾーン内では、子どもと親は 互いの主目的利用を行うために分離する利用、中でもく繰り返し> 型が多くなり、Activeゾーンの各エリアの座席が充実していれば、子 どもは付き添い読書等の拠点利用により、親とともに利用エリアは ポピュラーライブラリーエリアや雑誌エリアなどゾーン内に拡がる。 3）一方で、成人の単独利用時は複合利用や書籍の併用利用で両ゾー ンを行き来すること、また、ファミリー利用の親と小高学年はActive ゾーンで過ごしながらも短い時間でQuietゾーンを利用する者もいる こと、しかも、両ゾーンの視覚的連続性によって子どもの一般書エ リア利用時間は影響を受けやすいことから、Active ゾーンと Quiet ゾーン、中でもポピュラーライブラリーエリアと一般書エリアは遠 くに切り離すのではなく、できるだけ近くに配置する方が望ましい。

尚、本研究は平成 $13 \sim 15$ 年度文部科学省科学研究費補助金 (基盤 研究 C (2))による。

\section{注}

注1）参考文献4）で定義しているが、再掲すると、利用者が多く、かつ、ファ ミリ一利用で同伴する親が利用しやすい書籍や、新聞・雑誌と複合利用され やすい書籍を集め、これをポピュラーライブラリーと呼び、これらが配架さ れたスペースをポピュラーライブラリーエリアとする。

注2） AVエリアは二つに分かれ、視聴コーナーに CD 等が配架され、雑誌エリ ア横にはビデオテープが配架されている。

注 3）建物は 2 階建てであり、2 階は学習室、お話し室、準備室等である。当 初は、一般書エリアと児童書エリアを階で分ける案も検討されたが、利用を 考慮し二つのエリアを 1 階に持ってくる案に落ち着いたものである。

注4）H館のポピュラーライブラリーエリアには雑誌架に面して机があり雑誌 利用が考えられるが、ポピュラーライブラリーに囲まれているため、エリア としてはポピュラーライブラリーエリアに入れている。

注 5) $\mathrm{AV}$ 資料は $\mathrm{S}$ 館は $\mathrm{CD}$ （1157 点）と映画等のビデオ（1979 点）が中心で あり、視聴ブースも5 席ある。それに対して、H館はカウンター横にカセッ
トテープ（296点）と CD（117点）が配架され、ビデオ（1057点）は郷土 資料的なジャンルのものが 2 階の学習エリアの一部に配架されている。 注6)調查中に別のファミリーの一員であることが判明した場合等は調查を中 止した。なお、調查後、子どもが中学生のケースが3例あり、サンプルから 除いた。

注 7）父母以外は叔父 1 人、祖母 3 人である。

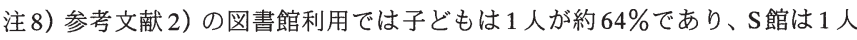
約 $59 \%$ とそうかわらない。

注 9）ここではActive ゾーンが形成されている図書館利用と区別する意味で、 Active ゾーンが形成されていない参考文献 2）3）の図書館利用を一般の図 書館利用とした。その調查対象図書館概要を以下に再揭する。

\begin{tabular}{|c|c|c|c|c|}
\hline 図書館名 & OM市立図書館 & YA市立图畫館 & MN図畫館 & YO市立图墨館 \\
\hline 空間の型 & 切り噰し型 & 切り囃し型 & 隣接型 & 糍接型 \\
\hline 延べ床面積 & $2,203 \mathrm{~m}^{2}$ & $2,873 \mathrm{~m}^{2}$ & $1,587 \mathrm{~m}^{2}$ & $2,290 \mathrm{~m}^{2}$ \\
\hline 開架フロア一面積 & $1,633 \mathrm{~m}^{2}$ & $1,474 \mathrm{~m}^{2}$ & $1,131 \mathrm{~m}^{2}$ & $981 \mathrm{~m}^{2}$ \\
\hline \multirow{3}{*}{$\begin{array}{c}\text { 藏書数 } \\
\text { 開架冊数 }(\text { (一般書) } \\
(\text { 児童書 })\end{array}$} & 179,798 冊 & 134,551 冊 & 125,953 冊 & 213,467 冊 \\
\hline & 約9.7万冊 & 約10.1万冊 & 約7.2万冊 & 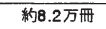 \\
\hline & 約 2.8 万冊 & 約3万冊 & 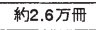 & 約2.5万冊 \\
\hline 新闃種数 & 12 種 & 14 種 & 6種 & 24 種 \\
\hline 雔誌多仆川数 & 141 多怗 & 215 外仆 & 15191kll & 564 多仆 \\
\hline$A V$ 点数 & 3078 点 & 5728 点 & 1742 点 & なし \\
\hline 本の貸出冊数制限 & 制限なし & 制限なし & 10 冊 & 制限なし \\
\hline 市民一人当たり貨出冊数 & $4.1 \mathrm{~m} / \mathrm{\lambda}$ & $7.2 \mathrm{~m} / \mathrm{h}$ & $8.0 \mathrm{f} /$ / & $9.2 \mathrm{~m} /$ 人 \\
\hline
\end{tabular}

なお、このうち参考文献 2）は4図書館全部、参考文献 3）はOM、YA、YO の3図書館を対象としたものである。

注 10）参考文献 2）参照。

注 11）参考文献 2）参照。

注 12)この<絽り返し>型は、分離回数が 1 7 回までと様々であるが、平 均すると $2.2 \sim 2.5$ 回分離している。また、平均の分離時間は約 $10 \sim 14$ 分 で付き添い時間約 $24 \sim 26$ 分の約半分であり、 $\mathrm{S}$ 館と $\mathrm{H}$ 館で差は小さい。

注13) 子どもの対象書籍は主に児童書であるが、6章に記したように小高学年 になると一般書の併用利用が増える。そのため、ここでは書籍と記した。

注 14）親に主目的利用がないため、資料利用がない O 型に含めた。

注 15）参考文献 6) 参照。尚、参考文献 6) では $\mathrm{S}$ 館 1.23 と記したが 1.19 の誤 りである。

注 16）参考文献 6）参照。

注 17）参考文献 3）では、親の性別は母親が平日は約 $87 \%$ 、休日は約 $60 \%$ で あったが、今回は休日にも関わらず、母親は約 70〜 78\%と多い。

注 18）<前半分離>型の子どもで小高学年の兄弟が同伴したケースは S 館は $7 / 14$ 例に対して、H 館は $2 / 19$ 例と少なく、小高学年の兄弟が同伴したケー スは滞在時間が長くなり、特に幼児で顕著である (参考文献 2) 参照)。 注 19）＜後半分離>型は $\mathrm{H}$ 館は 2 例、 $\mathrm{S}$ 館は 4 例であり、 $\mathrm{H}$ 館の 1 例のみが滞 在時間 69 分と長くなっており、もう 1 例は 15 分と $\mathrm{S}$ 館の 4 例の平均とそう かわらない。

\section{参考文献}

1) 北岡敏郎ほか: 成人の複合利用からみた公共図書館のコーナー構成とブラ ウジングについて, 日本建築学会計画系論文集,第 486 号,pp61〜 68,1996.8

2) 北岡敏郎ほか : 図書館利用型の構成とその特徴 ファミリー利用からみた 公共図書館のコーナー構成に関する研究 (1)，日本建築学会計画系論文集, 第 498 号,pp117 $122,1997.8$

3) 北岡敏郎ほか : <分離>利用型の特幑と児童書コーナーと一般書コーナー の配置構成 ファミリー利用からみた公共図書館のコーナー構成に関する研 究 (2)，日本建築学会計画系論文集,第 518 号,pp129～135,1999.4

4) 北岡敏郎 : ポピュラーライブラリーエリア創出の可能性 地域公共図書館 における開架フロアのゾーニング手法に関する研究 (1), 日本建築学会計画 系論文集,第 73 巻,第 626 号,pp751〜 756,2008.4

5) 北岡敏郎: ポピュラーライブラリーエリアの形成と資料構成案 地域公共 図書館における開架フロアのゾーニング手法に関する研究 (2), 日本建築学 会計画系論文集,第 74 巻,第 638 号,pp751〜 760,2009.4

6) 北岡敏郎 : Active ゾーンを形成した図書館における成人利用の特徵 地域 公共図書館における開架フロアのゾーニング手法に関する研究 (3), 日本建 築学会計画系論文集, 第 75 巻, 第 652 号,pp1365 1371,2010.6

(2011年 1 月 7 日原稿受理，2011年 6 月 8 日採用決定） 